\title{
A PIONEER COMMUNITY: THE PALEONTOLOGICAL SOCIETY TAKES ITS PUBLICATIONS ONLINE!
}

\author{
PATRICIA H. KELLEY \\ President, The Paleontological Society
}

A mong our geologic colleagues, paleontologists seem to have the undeserved reputation of being somewhat stodgy and reluctant to accept change; I guess this comes with our (also undeserved) "stamp collector" image. How then to explain The Paleontological Society Council's bold decision at our Incoming Council meeting in Reno last November? Perhaps it was from being surrounded by all those gamblers, but Council voted unanimously to take our publications online beginning in 2001.

I thank the editors of the Journal of Paleontology for providing me the opportunity to explain on behalf of Council how we arrived at our decision, the benefits and risks involved, and how Paleontological Society members can begin to take advantage of our online journals. I emphasize that the decision was reached after extensive research by the PS journal editors (including conversations with other societies and multiple vendors and development of detailed budget projections), careful articulation of the options (particularly by $\mathrm{Pa}$ leobiology co-editor Scott Wing), and hours of debate within Council. Despite a certain degree of risk to the Society's finances (as Treasurer Tom Kammer, always mindful of the bottom line, was careful to point out), we decided that now was the time to move forward.

We knew that electronic publishing was going to become necessary eventually-the question was how soon and how wholeheartedly should The Paleontological Society go online? Should we be pioneers in this effort, or jump on the bandwagon only after other societies had taken the initial risk? Should we ease into it gradually, one publication at a time?

Electronic publishing carries a financial risk; although paper publication of our journals may eventually be superceded, the Society is currently adding the expense of online publishing to our existing costs of producing paper copies. However, the purpose of The Paleontological Society is not to make money, but to advance the science of paleontology. As argued by the journal editors, online publishing will provide a better service to our members and subscribers, enlarge our readership, disseminate paleontological research more effectively, maintain or raise the visibility and reputation of our journals, give institutions the paperless format they so strongly prefer, increase both journals' impact factors (a number important to institutions in determining whether to subscribe to a particular publication), and heighten the awareness of paleontology by the public and other sciences.

And so we voted to publish an online version of both Journal of Paleontology and Paleobiology beginning in January 2001. There were financial benefits to taking both journals online simultaneously, and additional savings were found by joining and publishing through BioOne, a consortium of academic libraries, the American Institute of Biological Sciences, and Allen Press. BioOne currently provides online access to 32 journals, including Evolution and the Journal of Vertebrate Paleontology. BioOne provides the most reasonable entrée into this venture, will market our journals professionally, and gives us some financial protection against institutional subscription losses. However, individuals will only be able to access our journals through BioOne if their institution is a BioOne subscriber. To provide online accessibility for all PS members, we also decided to establish a standalone ("silo") site through Allen Press, the publisher of our journals. (Libraries can subscribe to the silo site as well if they are not a BioOne subscriber.)

So, by the time you read this, both Journal of Paleontology and Paleobiology will be available at BioOne <http://www.bioone.org/ bioone/?request $=$ index $-h$ tml $>$. If your institution subscribes to BioOne you will have full access to all articles; otherwise you will only have access to titles and abstracts. However, the journals will also be available at the silo site <http://www.psjournals.org $>$, and abstracts and titles for recent volumes are also available free at $<$ http: //apt.allenpress.com/ $>$. Take a look-the silo site will be free throughout the rest of 2001. We expect that you will enjoy the ease of online access, the browsing and search capabilities, and the ability to move from one article to another by clicking on a reference. And at a bargain price ( $\$ 10$ for Journal of Paleontology, $\$ 5$ for Paleobiology), you can add an online subscription to your paper copy of the journal starting in 2002 !

Additionally, the Paleontological Society Council, at its MidYear meeting in March, decided that this was the appropriate time to move to online publication of our newsletter, Priscum. Peter Harries will be the new editor of Priscum, and is ready for the online challenge. Watch for a postcard announcing the online publication of Priscum on the Society's web page (please note that the web page has been transferred to the PS secretarial office at the University of Alabama; it can still be accessed at <paleosoc.org $>$ ). Priscum will be available as a downloadable PDF file using Adobe Acrobat Reader, which is freeware <http:// www.adobe.com/products/acrobat/ $>$. You will be able to read Priscum on your computer screen or print a paper copy. We will be asking all members to provide a current email address when they renew their membership for 2002 and will use these addresses to announce future online issues of Priscum.

In order to make the new publishing adventure possible, as well as cover inflationary costs associated with publishing our journals, Council passed a modest dues and subscription increase for next year. Dues for regular and retired members will increase by $\$ 5$ next year, and Paleobiology subscriptions will increase by $\$ 3$. (Consistent with Council's desire to encourage student membership in the Society, PS student members will not see an increase in their dues and subscriptions, however.) Institutional subscriptions will increase by 10 percent.

I wish to thank a number of people for their efforts over the past couple years in bringing the Paleontological Society to this point. Although all Council members over the past two years participated in the decision-making progress, online publication was particularly championed by Peter Crane, my immediate predecessor in the presidency. Special thanks go to Paleobiology editors Scott Wing and Doug Erwin, and Journal of Paleontology editors Nancy Budd, Brian Witzke, Julia Golden, and Jonathan Adrain. The journal editors were diligent in exploring the online options, patient in explaining terms such as "SGML" and "silo" to less technologically informed Council members (I'm referring mostly to myself), and persistent in pursuing this option.

And we are true pioneers, by the way. In February, I attended a meeting of presidents and/or executive directors or other representatives of the 24 Associated Societies of the Geological Society of America. One of the significant issues discussed at the meeting was online publishing. To my surprise, The Paleontological Society is at the forefront in this area. Only two other societies are publishing their journals online, the Mineralogical Society of America and the Society of Vertebrate Paleontology (both began, as we did, in January 2001). The Paleontological Society was an example held up to all our geochemical, geophysical, etc., colleagues.

Who says paleontologists are stodgy! 